\title{
Pastoralism, conservation and resilience: causes and consequences of pastoralist household decision-making
}

\author{
KATHERINE HOMEWOOD \\ University College London \\ MARCUS ROWCLIFFE \\ Intitute of Zoology, London \\ JAN DE LEEUW \\ ISRIC World Soil Information, Wageningen \\ MOHAMED Y. SAID \\ Institute for Climate Change and Adaptation (ICCA), University of Nairobi and \\ Norwegian University of Science and Technology \\ and \\ AIDAN KEANE \\ University of Edinburgh
}

\section{Introduction: pastoralism and conservation in sub-Saharan Africa's arid and semi-arid lands}

Recent estimates put global pastoralist populations at around 120 million people, ${ }^{1}$ those of sub-Saharan Africa at around 50 million (plus 200 million agro-pastoralists: Inter-Réseaux Développement Rural, 2012) and those of the Horn of Africa (including East Africa) at between 12 million and 22 million people. These are debatable figures. There are different definitions of what constitutes a pastoralist, ranging from 'someone who depends primarily on mobile livestock, extensively reared on open range' to 'someone who selfidentifies socially and culturally as a pastoralist, even though (s)he may own no animals and may rely primarily on other livelihood activities'. Many pastoralists and most observers of pastoralism agree that both definitions are valid. This is because the vagaries of pastoralist lives are such that any one individual, household or community may move to and fro between the two extremes once or more in the course of their life cycle. As well as the fluidity of definitions, there are complexities around population estimates because of pastoralists' spatial mobility (whether managing animals, or temporarily

1 www.worldbank.org/en/news/press-release/2014/03/18/world-bank-pastoralists-horn-africa (accessed 27 March 2014). 
otherwise engaged) and their often remote locations. Few sub-Saharan nations have good census data on mobile people or on mobile production systems.

Two-thirds of Africa south of the Sahara is arid or semi-arid. In these areas rain-fed cultivation is risky at best, but livestock can move to exploit key grazing, water and mineral resources, and to avoid seasonally high populations of disease vectors, or areas that are temporarily unsafe because of conflict or raiding. By the same count, enterprises based on relatively mobile wildlife may be very profitable. So, for example, wildlife-based tourism is regularly listed among the top three contributors to national GDP in both Kenya and Tanzania (Homewood et al., 2012). These official figures usually overlook the very significant contribution of pastoral livestock production to national GDP. Although largely invisible to the official gaze, that contribution, where it has been fully evaluated, is estimated to match agricultural GDP from crops (Behnke \& Muthami, 2011).

Because both wildlife and pastoralist livestock exploit open rangelands, there are potential synergies between the two enterprises (du Toit et al., 2010). Those synergies hinge particularly on mobility across unfenced, non-fragmented, extensive rangelands, allowing domestic and wild herbivores to seek out the best conditions of pasture and water, and to minimise challenge from biting flies and environmental diseases. Through their grazing, burning, nutrient redistribution and waterhole maintenance, pastoralists and their herds exert a positive influence in shaping grazing lands for wildlife as well as for themselves (Mershall et al., 2018). A large literature explores the rich biodiversity of current and former pastoralist rangelands (Sinclair et al., 2008); the density and health trade-offs between wildlife and livestock where these compete for key resources of forage and water (Prins, 2000; Odadi et al., 2011; Butt \& Turner, 2012); where they prevent (Sinclair \& Arcese, 1995) and/or transmit infectious diseases between themselves; and the thresholds at which optimum combinations of wild and domestic herbivores can be maintained (Sinclair et al., 2008; Niamir-Fuller et al., 2012; Western et al., 2009a, 2009b). Pastoralist herds thus make a very major economic contribution to the wildlife sector, for example in Tanzania (Nelson, 2012).

East African rangelands in particular are famous both for their pastoralist and their wildlife populations, but their social and environmental sustainability is in doubt. Pastoralist livestock production is important both to local livelihoods (Homewood et al., 2009) and to national economies (Behnke \& Muthami, 2011), yet most of these peoples are chronically poor. The same rangelands are renowned for their biodiversity, with wildlife tourism income a major component of national GDP, but the wildlife populations are in drastic decline (Craigie et al., 2010; Western et al., 2009a, 2009b; Ogutu et al., 2012), threatened by changes in land use (Norton Griffiths \& Said, 2010; Homewood et al., 2001), possibly exacerbated by climate trends. 
Pastoralism thus presents conservation enterprises both with complementarities (Nelson, 2012) and also with possible conflicts. Many national or international conservation agencies prefer to exclude pastoralists and livestock from protected areas set aside for conservation. This is often justified on the basis of environmental degradation narratives, even where demonstrably far more damaging extractive endeavours are favoured in their place (Walsh, 2008; IWGIA, 2013).

At the same time, many pastoralists complement their own livestock-based livelihoods with farming, however low and risky the returns, converting rangeland in ways that may exclude most large mammal wildlife and other valued components of biodiversity. While fragmentation due to the spread of small-scale settlement and farming affects wildlife (Ogutu et al., 2012), largescale farming for cash crops may displace them completely, driving major declines (Homewood et al., 2001). As the global human population continues to grow, pressure from national and international investors intensifies to convert sub-Saharan rangelands to large-scale cultivation of food, fuel or fibres, and to capture already limited water resources with which to irrigate these otherwise unpredictably rain-fed arid and semi-arid lands (ASALs) (e.g. Catley et al., 2012; Fratkin, 2014; Galaty, 2014). Although pastoralism, wildlife and farming have coexisted for millennia across sub-Saharan Africa, these rangelands are shrinking under the combined pressures of land conversion for large-scale cultivation, and land set-aside to meet international and national conservation targets (Lambin \& Meyfroidt, 2011; Fairhead et al., 2012; Galvin et al., 2018). Pastoralist populations and their livelihoods are being squeezed into ever more constrained areas with ever dwindling prospects for mobility. Where mobility has allowed pastoralists across subSaharan Africa to survive through extreme events of drought, epidemic and conflict over the last 4000-5000 years, this central coping strategy is now threatened (Galaty, 1999; Niamir-Fuller, 1999; Reid et al., 2014). At the same time, wildlife populations are in sharp decline across pastoralist rangelands, despite the large and increasing areas set aside for them and the high earnings they bring to governments and entrepreneurs, because land conversion, and land fragmentation with privatisation, limit mobility - and therefore survival - for wildlife as much as for pastoralists and livestock.

Past and current work on pastoralist household decision-making, land use and livelihoods is central to the debate over the resilience of pastoralist social-ecological systems (SESs) and over resilience thinking more generally. Pastoralist strategies have long been recognised as managing risk in ways that absorb the shocks and stresses of sub-Saharan Africa's ASALs' unpredictable, fluctuating biophysical and socioeconomic environments (Davies \& Nori, 2008). They have also long been recognised as displaying ongoing dynamic innovation and adaptation (Galvin, 2009; Catley et al., 2012). The emergence 
and survival of pastoralism in sub Saharan Africa over the last 4000-5000 years, and the survival of the African savanna megafauna (including large predators) into the twenty-first century are measures of the social and environmental sustainability of the system. However, for all its past and continuing internal resilience as a production system within ASALs, the continued survival of pastoralism and its continued coexistence with wildlife through the twenty-first century are now both under threat.

This chapter starts by considering multi-scale resilience of pastoralist SESs and associated biodiversity, the complementarities and conflicts of biodiversity conservation with these SESs, and the extent to which trends in pastoralist economics and ecology can be understood through and informed by resilience thinking. The chapter goes on to outline a conceptual model of the main biophysical and socioeconomic processes these SESs encompass, and to set out the main dimensions of mobile pastoralism in sub-Saharan African (sSA) rangelands.

Shocks, stresses and opportunities engendered by unpredictable, fluctuating biophysical and socioeconomic conditions are integrated at the level of individual households. In making decisions about whether (and to what extent) to herd livestock or pursue wildlife-based enterprises on open rangeland, or to convert land to small- or large-scale farming, households are evaluating these multi-dimensional trade-offs. Individual household-level decisions aggregate to shape landscape-level trends affecting the viability of pastoralist systems and of wildlife populations. We introduce our work on household decision-making by first outlining what constitutes the pastoralist household and what this unit of analysis entails.

We go on to describe current research on pastoralist household decisions, their determinants and outcomes. Building on empirical ethnographic and livelihoods data from earlier multi-site studies across Kenya and Tanzania Maasailand (Homewood et al., 2009), current research uses economic games, choice experiments, stochastic dynamic programming and other modelling approaches, alongside empirical work, to explore the way trade-offs (and decisions) vary between locations and households of different wealth, shifting with rates of return from different enterprises and with policy incentives or constraints. To date, this work has focused on household decisions in and around Kenya's proliferating conservancies, particularly around the Maasai Mara National Reserve (MMNR), its highest-earning wildlife area. Conservancies are defined by Kenya's Wildlife and Conservation Management act of 2013 as 'Land set aside by an individual landowner, body corporate, group of owners or a community for purposes of wildlife conservation'. They now number some 160 across Kenya (over 100 being wildlife- and others forest-related), covering several thousand square kilometres of rangelands, and are hailed as an effective answer to poverty and conservation issues, although more nuanced 
perspectives are starting to emerge (Osano, 2013; Bedelian, 2014). Further work now in progress explores the contrasting situations engendered by Tanzania's Wildlife Management Areas, originally conceived as a national programme for community-based natural resource management initiatives and as a key component of the national Poverty Reduction Strategy. We expect that our emerging findings will be generalisable to other sub-Saharan rangelands across the Horn of Africa and beyond, particularly in terms of their underlying approaches to understanding people's choices and to scoping policy scenarios.

\section{Resilience of pastoralist SESs}

Studies of pastoralist household strategies tend to use resilience thinking in either more applied or more theoretical ways. Applied work focuses on resilience thinking as a framework for understanding risk coping strategies and disaster management, and as a potential tool in prioritising need for humanitarian and development aid (Oxfam, 2010; Robinson \& Berkes, 2010; DFID, 2011). These applied approaches build to a significant extent on earlier understandings of risk and vulnerability (Wisner et al., 2004). For example, Robinson and Berkes (2010) look at the potential of resilience approaches to identify surrogate indicators of stress and adaptation among Gabra pastoralists in northern Kenya. Building on the long-established understanding of pastoralist mobility, herd management and social risk spreading systems as adaptive strategies buffering shocks and stresses, they identify a set of indicators (species-specific herd numbers, specific dimensions of pasture condition, etc.) which can be tracked to reveal trends in vulnerable pastoralist populations potentially in need of humanitarian intervention.

Although not explicitly phrased in terms of resilience thinking, risk management and household outcomes have been studied in these same Gabra populations by McPeak et al. (2011), who have developed a useful classification of household trajectories. In their schema, households are categorised according to their economic position on two axes: livestock assets and income versus other assets and income. Households are categorised as being below or above average for each of these axes, giving rise to four household categories. These are:

(a) households with above-average assets and income from both livestock and other activities. These households are successfully combining pastoralism with diversification;

(b) households with above-average livestock assets but which are below average for other assets and income. These households are seen as staying on as pastoralists;

(c) households with below-average livestock assets and income but having above-average assets and income from other activities. These are seen as moving out of pastoralism; and 
(d) households that are below-average both for livestock and for other assets and income. These households are effectively being left behind in poverty.

While this approach gives a good rule of thumb, it is not necessarily the case that the average represents a realistic threshold: for example, average values in pastoralist SES are driven upwards by the few very wealthy households. However, the scheme brings home the way different strategies and outcomes lead to different possible futures, including the decline of pastoralist livelihoods, and thus of pastoralism, for households with decreasing livestock numbers.

More theoretical approaches (building on Folke, 2006) have analysed pastoralist strategies as a basis for developing resilience theory per se. Leslie and McCabe (2013) analyse individual-, household- and village-level responses to varying circumstances (particularly around differing interactions with national park and conservation easement initiatives) as forms of response diversity, in itself a dimension of functional diversity, as a central component of the resilience of pastoralist SESs. They describe the different strategies adopted by different individuals, households and villages in their interactions with the vigorous spread of state and private conservation set-aside across formerly communal rangelands in northern Tanzania. For example, at village level, these strategies include:

- opting to cultivate to forestall boundary extensions by the National Park;

- resisting creation of supposedly community-based natural resource management (CBNRM) Wildlife Management Areas, because of their failure to replace lost resource access and associated income with commensurate revenues, due to state and elite capture of revenues including payments for environmental services (PES) or payments for wildlife conservation (PWC);

- negotiating conservation easements with private tour operators, allowing villagers to graze their livestock in the set-aside, while agreeing not to cultivate or build there.

These variants, and comparable variation observed at individual and household level, can be related to the specific social and historical circumstances of each case. Interpreting them within the context of resilience thinking, Leslie and McCabe (2013) take the wider view that these variants are a manifestation of response diversity, forming the raw material underpinning the potential for adaptation and resilience.

Resilience thinking does not only seek to analyse and predict the possibilities of adaptation to and survival through shocks and stresses, it also considers the possibility of systems collapsing and reorganising as a new, different state, which is characterised by quite different components, processes and linkages 
(Folke, 2006). Across sub-Saharan Africa, especially in East Africa, the competition for land has become so intense and land grab by the state, by investors and elites so overwhelming (Zoomers, 2010), that rangelands available for pastoralism (and wildlife dispersal outside protected areas) are dwindling fast (Lambin \& Meyfroidt, 2011; Land Matrix, www.landmatrix.org/en/). In Tanzania, there have been high-profile forced displacements of many thousands of pastoralists and their herds in recent years (Loliondo: BBC, 2013; Usangu: Walsh, 2008; Morogoro: IWGIA, 2013). Similar events are taking place in Kenya (Laikipia: Letai \& Lind, 2012; Galaty, 2014; Tana River: Duvail et al., 2012); Ethiopia (HRBDF, 2013; Fratkin, 2014) and elsewhere. These evictions and associated land grabs are made all the more easy by land laws which generally do not recognise customary ownership of pastoralist grazing lands and official views holding that such lands are not in productive use. By contrast, farmland ploughed and sown with crops is recognised as being under private or customary tenure warranting at the very least compensation for any displacement.

Pastoralist SESs may therefore be highly resilient on all indicators of internal functioning, with livestock production contributing half or more of pastoral people's household incomes (Homewood et al., 2009, 2012) and of the national agricultural GDP (Behnke \& Muthami, 2011); displaying considerable response diversity (Leslie \& McCabe, 2013), innovation and adaptive capacity to deal with climatic and economic shocks and stresses (Davies \& Nori, 2008; Galvin, 2009; Catley et al., 2012) and showing finely calculated, rapid and effective responses to policy and economic changes (Keane et al., 2016). At the same time, though, despite this internal resilience, they are being pushed towards collapse by external drivers, with the state, and statenetworked investors, progressively capturing control of key resources of water and land and converting or removing these from the pastoralist SES, whether for cultivation or for conservation purposes.

Resilience thinking emphasises the need to look at multiple scales (Folke, 2006). Certainly in this case, internal resilience is negated by political and economic vulnerability on the national and international scale, in the context of twenty-first-century global population growth and globalisation processes. This raises the question as to quite what theoretical resilience thinking adds to our understanding of pastoralist SESs. It is perfectly possible to phrase pastoralist strategies and systems in resilience terms, but it is not clear that the exercise brings any newer insights or greater depth of understanding than do, say, risk management and political ecology frameworks.

Given the marginalised status of many pastoralist groups, the highly political use of poorly substantiated pastoralist degradation narratives to justify either displacement of pastoralist households from a coveted area, or privatisation of resources (which subsequently become available to global capital, whether for large-scale cultivation or for commercial conservation-based 
enterprises), and the universal nature of these processes (e.g. Sternberg \& Chatty, 2012), political ecology might be seen as the more incisive analytical tool in understanding trends in twenty-first-century pastoralist SES (Robbins, 2012). Political ecology, the political economy of natural resources control, exposes the interplay of vested interests, the impact of neo-liberalisation and of potential profits to state, external investors and local elites in capturing rangelands formerly under pastoralist common property management. It also makes clear the strategic use of narratives of pastoralism's low productivity and environmental degradation (Robbins, 2012). Pastoralist production is poorly captured by official statistics, and official policies commonly dismiss now widely available evidence of the ecological and economic efficacy and sustainability of pastoralist production. Narratives portraying pastoralism in a negative light are commonly used as tools in displacing pastoralists from rangelands targeted for large scale cultivation or conservation set-aside (Benjaminsen \& Bryceson, 2012; Galaty, 2014).

As the human population nears 9 billion, approaching or exceeding planetary boundaries on biogeochemical processes that have maintained a favourable, stable environment for the last 10,000 years (Rockström et al., 2009), African rangelands increasingly constitute the main remaining land area available for conversion to cultivation - but at great social and economic cost to their long-resident pastoralist inhabitants (Lambin \& Meyfroidt, 2011). Pastoralist livelihoods are squeezed between competing land uses, driven by global capital, for large-scale cultivation on the one hand and for national and international conservation set-aside on the other. In principle these competing forces are meant to be integrated at the local level through CBNRM, allowing communities and households to develop socially, economically and environmentally sustainable compromises. This is the picture presented in the Poverty Reduction Strategies of Tanzania and Ethiopia (e.g. URT, 2005, 2010) and on the websites and literature of many conservation initiatives. In practice, CBNRM outcomes for both environment and for poverty reduction have been mixed, and often disappointing (e.g. Blaikie, 2006; Nelson \& Agrawal, 2008; Dressler et al., 2010; Bedelian, 2014), or simply left undocumented. For example, recent work (Osano, 2013) explores the trade-offs between pastoralism and conservation in a series of papers around the potential of different types of PES schemes for poverty alleviation and adaptation to climate change in Kenya's rangelands, including conservancy (around Maasai Mara) and conservation easement schemes (Kitengela). While meticulous in flagging up theoretically possible negatives, Osano (2013) focuses on measuring the benefits of PES and PWC schemes among participants: the costs, particularly to those unable to participate, remain unexplored in his work. Other studies attempt a more balanced approach (Sulle et al., 2011; Bedelian, 2014; Homewood et al., 2015). Together with the behavioural economics 
approaches outlined in this chapter, ongoing empirical studies deliver a robust statistical approach using before/after, control/impact design and matched comparisons to evaluate the social and environmental impacts of conservation interventions in East African rangelands. ${ }^{2}$

\section{Conceptual model: factors shaping pastoralist household decisions}

In order to unpack further these ideas of resilience or the lack of it in pastoralist SESs, we now focus on pastoralist livelihoods, based loosely around the sustainable livelihoods framework (Scoones, 2009). This is informed by complementary approaches based on pastoralist perceptions of risk (Oxfam, 2010; McPeak et al., 2011), on understandings of pastoralist poverty (Anderson \& Broch-Due, 1999; Barrett et al., 2011); on pastoralist management of climate and environmental change (Davies \& Nori, 2008; Galvin, 2009) and on our understanding of diversification and change in African pastoralist livelihoods more generally (Fratkin \& Roth, 2005; Catley et al., 2012) and across African rural societies (Ellis, 2000). Our work is also informed by research on the poverty and livelihoods implications of conservation interventions in East African rangelands, from the economic (Emerton, 2001) to the more political (Jones, 2006; Adams \& Hutton, 2007; Igoe \& Croucher, 2007; Benjaminsen \& Bryceson, 2012), particularly around ostensibly community-based initiatives (Dressler et al., 2010; Nelson, 2010). This chapter goes on to look at the implications for our emerging understanding of pastoralist livelihoods and their interplay with biodiversity conservation, drawing on the rich tradition of scientific study of ecological processes and wildlife populations in East African rangelands (e.g. Sinclair \& Norton Griffiths, 1979; Sinclair \& Arcese, 1995; Sinclair et al., 2008).

In the course of earlier work, ${ }^{3}$ Homewood et al. (2001) established a conceptual framework bringing together the main biophysical and socioeconomic factors feeding into pastoralist household decision-making (Figure 9.1). The full model is explained in detail elsewhere ${ }^{4}$ (Homewood et al., 2009, chapter 1). In brief, building on past work, our conceptual model centres on the increasing competition between alternative uses (1) for land area overall and (2) for net primary production within the grasslands, between competing wildlife and livestock. Cash crop prices and policies drive the extent of large-scale commercial farms and of their associated ecological impacts. Small-scale farming is driven by population growth, migration and education - all factors affecting aspirations and economic trade-offs between

${ }^{2}$ ESPA-funded Poverty and ecosystem impacts of payment for wildlife conservation initiatives in Africa: Tanzania's Wildlife Management Areas (PIMA: NERC grant NE/L00139X/1) UCL PI

${ }^{3}$ EU-DGXII-funded Savanna Land Use Policy Outcomes, UCL with Prof Eric Lambin and Suzy Serneels, then of the Catholic University of Louvain.

${ }^{4}$ See also short video at www.ucl.ac.uk/best 
alternative livelihoods. Biophysical factors (rainfall, fire, ground water, grazing and browsing populations, etc.) influence the proportional extent of woodland and grassland in land that has not been converted to cultivation. These processes lead to active trade-offs by individual Maasai deciding whether to herd livestock or to run wildlife-related enterprises on open rangelands. They also involve trade-offs in whether to convert land to small- or large-scale farming. Trade-offs around land-use and labour investment decisions are calculated at the level of the individual household. Those calculations are influenced by social hierarchies and institutions, which affect the distribution of access to and benefits from resources and shape the different types of revenues available (Figure 9.1).

Thus, household-level decisions driving major changes in the study region are made on the basis of:

- revenue from different enterprises (herding, farming, wildlife, tourism),

- distribution of revenue between households,

- how people manage their assets, with livestock remaining a major potential wealth store and investment, and

- intangible, non-monetary values attached to livestock-related activities rather than other occupations. Owning livestock and successfully managing a herd carries 'social capital' in pastoralist societies. People make

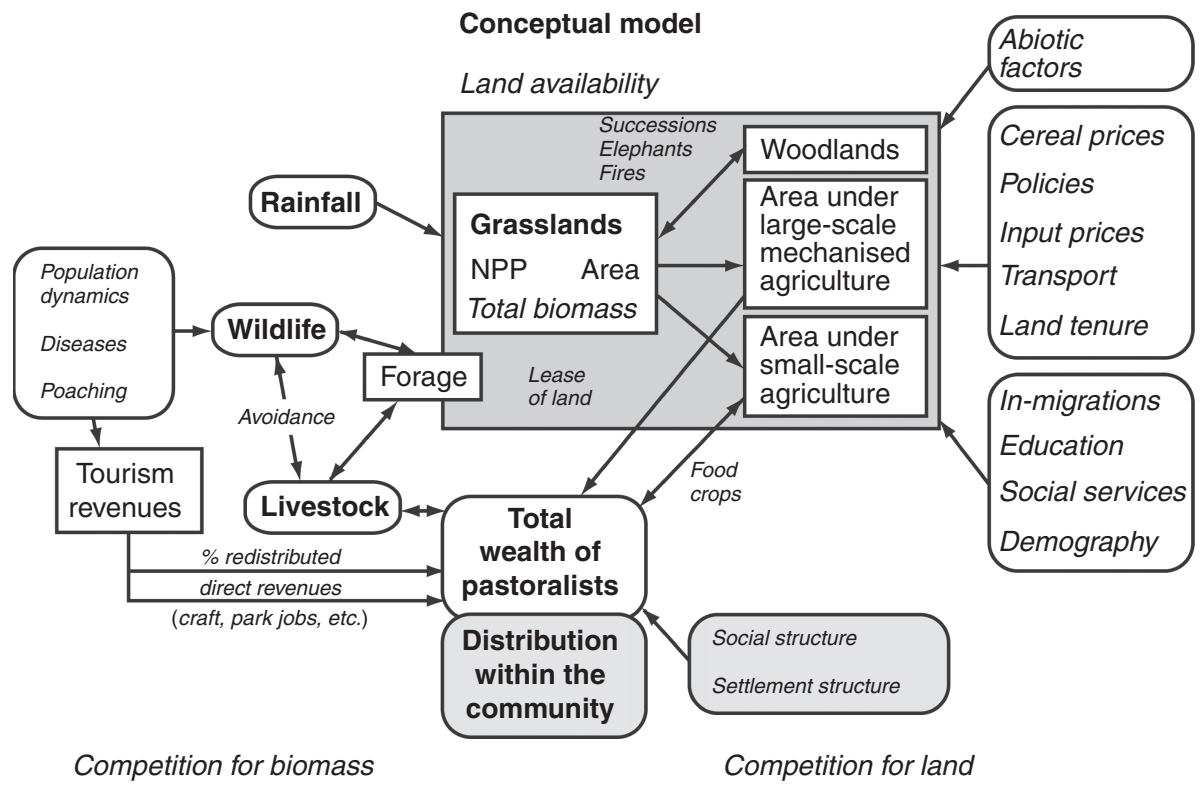

Figure 9.1 Conceptual model of the main drivers of pastoralist household decision making: see Homewood et al. (2001) and Homewood et al. (2009) for full exposition. 
choices that safeguard their standing within the social group and hence their ability to call on that group in possible future times of need. This is tied up with the concept of respect, and self-respect within one's social group (enkanyit, in Maasai culture; 'pulaaku' among Peul or Fulani pastoralists); concepts central to people's well-being (Gough \& McGregor, 2007; Agarwala et al., 2014; Milner-Gulland et al., 2014).

Finally, irrespective of limited yields, farming may be effective in staking a claim to land in a way herding does not, because governments often do not recognise customary communal tenure of pasture land as official ownership. Therefore, decisions to farm may represent a tenure strategy as much as an economic choice, especially when there is the prospect of formerly communal lands being subdivided and allocated as private plots. Similarly, it may represent a pre-emptive bid for subsequent compensation if local people suspect that formerly communal lands may be expropriated by the state and leased to investors for large-scale cultivation or wildlife-based enterprises.

These decisions, taken on the basis of site-specific trade-offs evaluated at the level of the individual household, aggregate to shape landscape-level changes in the amount and distribution of land converted to cultivation, land set-aside for wildlife conservation and land available for pastoralist livestock production, and for the mobility essential for both livestock and wildlife populations needing to access shifting key resources.

\section{Methodological note: the pastoralist household}

As we focus on the pastoralist household as the main unit of economic and ecological analysis, it is important to flag up an underlying conceptual issue around pastoralist households.

The standard definition of a household might read: "the basic residential unit in which economic production, consumption, inheritance, child rearing, and shelter are organised and carried out'; [the household] 'may or may not be synonymous with family' (Haviland, 2003). It is an often unspoken assumption that the concept of the household is readily transferable across places and cultures, but this general definition may not apply in very different socio-cultural contexts of pastoralist societies (Randall et al., 2011). This is particularly the case where people are extremely mobile and where individuals of different ages, genders or wealth may move through different patterns of residence, subsistence and migration both through the year and in the longer term. Also, where men are often polygamous, wives may not be co-resident, and men may divide their time, and their assets, equally or otherwise between spatially distant homesteads. In surveys and censuses, this may lead to one unit being recorded as male-headed and as endowed with the male household head's assets (radio, bicycle, mobile phone, etc.), 
and the other as a female-headed household without assets, where these superficially separate units would be better understood as a single bi-local, polygamous household under a single male head, with both units sharing his occasional presence and his assets to some extent (Randall et al., 2011). Alternatively, households may be multi-local, with related units in complementary locations (pastoral rangeland homestead with livestock; upland- or wetland-based homestead with farmed land; urban base hosting wageearners, children in school, relatives attending hospital: see for example Homewood et al., 2009, pp. 45-47, 151-158).

As much of the present chapter focuses around Maasai pastoralist systems in East Africa, we illustrate the potential complexity of the household concept in pastoral societies by outlining the different structural levels contributing to the concept of the household among Maasai. Here, the 'household' refers to the Olmarei (pl. Ilmareita), which may be best understood as the family of one household head with his or her dependants. These may include, in the case of male-headed households, more than one wife and her children and grandchildren, as well as the household head's parents and dependent siblings, together with non-related individuals who reside with the family and depend on them for food in return for assistance with household chores (most commonly herding).

The Olmarei may or may not be spatially and physically congruent with the homestead (Maa: enkang Pl. Inkang'itie), as the wives of a polygamous male Olmarei head may or may not be co-resident. Customarily they do often co-reside within a single homestead, with each wife building a small house (aji) for herself, her children and the occasional presence of her husband. The physical structure, positioning and occupancy of such houses have been described elsewhere (Spencer, 1988; Homewood \& Rodgers, 1991; Coast, 2002), but broadly speaking, the enkang customarily comprises a number of these enkaji (Pl. inkajijik) built around one or more linked livestock corrals.

Men traditionally lived in their wife's house or moved between several wives' houses. Increasingly, men invest - if they can - in a house of their own, built to a 'modern', non-traditional design (rectangular plan, mud and wattle walls, if possible with plaster, cement floor and corrugated iron roof). Such houses may be built at the rural homestead (and often used as a store and site of more formal meetings). In some cases men invest in modern houses located in trading centres or urban sites as a business or property investment, and may place one of their wives there to manage it, generating a multi-local household. Other multilocal households with two or more related bases might be in other complementary locations (upland- or swamp-based farm as well as pastoral rangeland and urban settlement). 


\section{Ecological and economic approaches to analysing drivers and outcomes of pastoralist household decisions}

The conceptual model and issues described above have informed several subsequent studies. The conceptual model formed the basis for a multi-site study of the ways land use and livelihood choices vary in different parts of Kenya and Tanzania Maasailand (Homewood et al., 2009, 2012). ${ }^{5}$ Together with the site-specific relevance and idiom conferred by local knowledge, the model has also informed the design of economic games, choice experiments, stochastic dynamic programming and other models exploring the implications of different climate events and policy/economic incentives for household decisions. ${ }^{6}$ The model also underpins research currently in progress on poverty and ecological impacts of Tanzania's Wildlife Management Areas, both in pastoralist rangelands and in miombo woodland areas (Bluwstein et al., 2018).

The multi-site study of land use and livelihoods (Homewood et al., 2009, 2012) showed that across Maasai rangelands in Kenya and Tanzania, livestock remain the central pillar of people's livelihoods, accounting on average for around half or more of household income in all sites (Figure 9.2). In four of five sites, off-farm wage or salaried work, including remittances, constituted the second and crops the third most important source of income. In four of five sites, wildlife-based income was the least important, accounting for less than 5 percent of household income on average, and contributing to fewer than 15 percent of households overall in any one site. However, in households around the Maasai Mara National Reserve, Kenya's highest-earning wildlife area, wildlife-based income contributed around 20 percent of household income on average across all wealth quintiles, and flowed to over 50 percent of households (Thompson et al., 2009; Homewood et al., 2009, 2012). Although these figures dropped off with declines in tourism during periods of electionrelated disruption, with a progressive concentration of revenues in the hands of the wealthiest quintile, land-owning households have subsequently showed a consolidation and on average a doubling of conservation-related income (Bedelian, 2014).

Building on both the conceptual model and on these initial empirical data on livelihood choices and household incomes, recent work designed economic games, choice experiments and policy scenario models (Figure 9.3a,b), looking at the following questions.

- How does conservation set-aside affect pastoralist household decisions over land use and livelihoods?

${ }^{5}$ Belgian DGIC-funded Reto-e-Reto research collaboration, led by Robin Reid, then of ILRI Nairobi, UCL Co-I.

${ }^{6}$ ESPA-funded project Biodiversity, Ecosystem Services, Social Sustainability and Tipping Points in East African Rangelands (ESPA-BEST: NERC grant NE/1003673), UCL PI. 


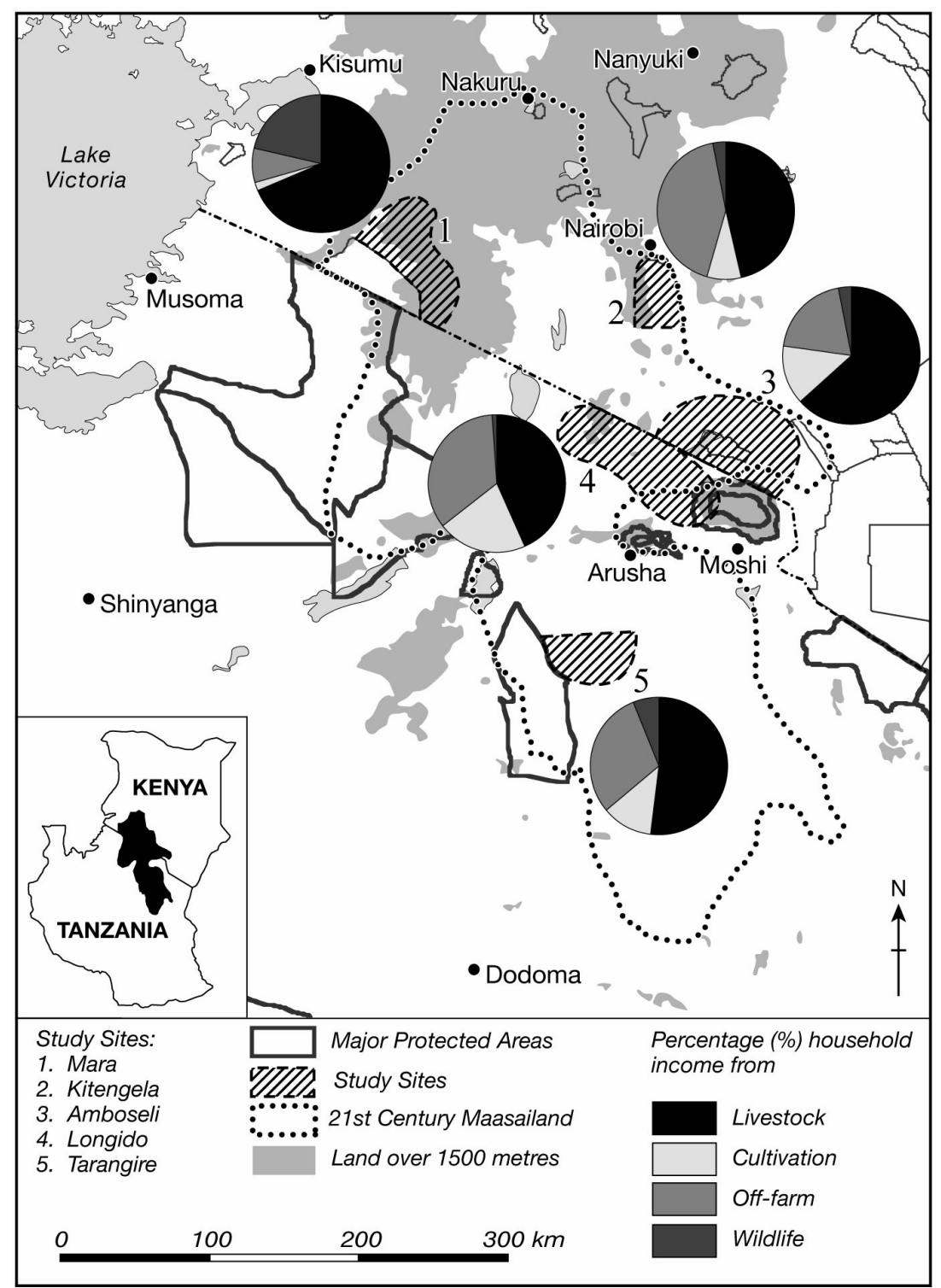

Figure 9.2 Study sites, land use and livelihoods in Maasai rangelands in Kenya and Tanzania.

- What are the economic and ecological outcomes of these decisions and the trade-offs they involve?

- How do impacts differ by age, gender and wealth and between households in different circumstances (e.g. conservancy members versus non-members)?

- What are the unanticipated outcomes of policy and economic incentives? 
(a)

\section{UNDERSTANDING FROM EXISTING DATA SETS}

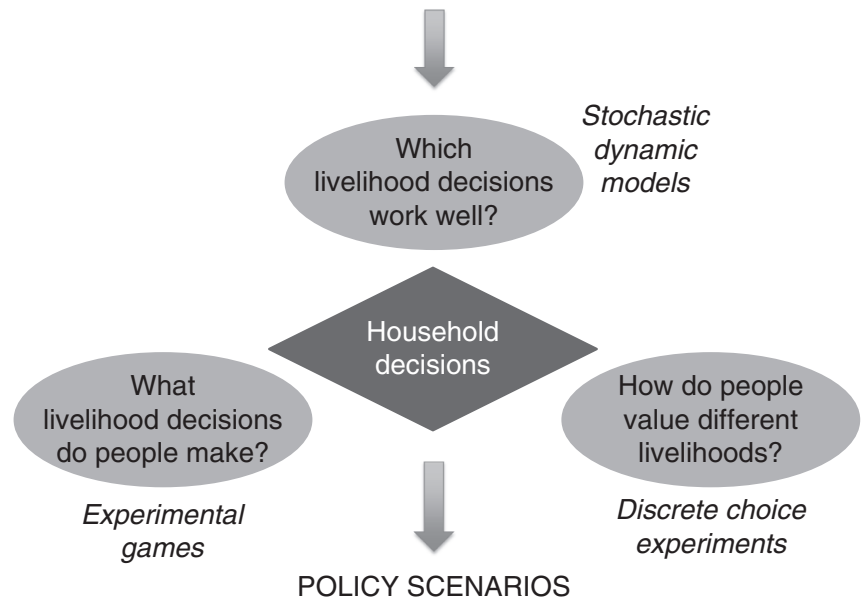

(b)

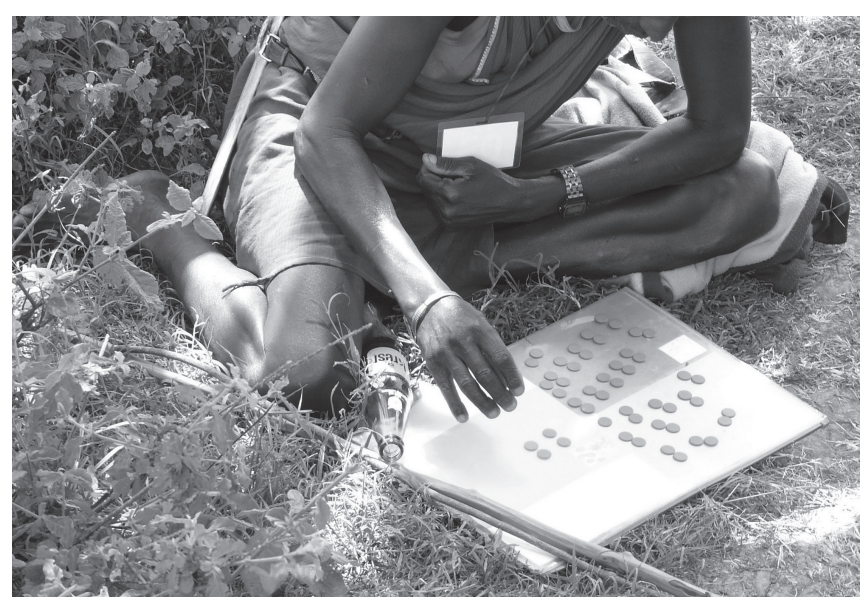

Figure 9.3 (a) Questions and tools used to explore the decision-making process in pastoralist households. (b) An economic game where the blue counters represent wealth held either as cash or livestock. The blue square on the board represents the bank: this player chooses to hold only a small part of his wealth there. The green square represents his own land, with more of his wealth held as livestock on this private grazing. The largest share of his wealth is held as livestock grazing illegally in the Maasai Mara National Reserve, represented by the red square on the board. These games and choice experiments revealed the extent to which pastoralists' strategies (and theoretically optimal choices) shift according to household wealth and land tenure context, as well as individual characteristics (age, gender, education ...), and the unanticipated outcomes of poorly-conceived conservation policies. These contextsensitive strategies represent an important dimension of response diversity crucial to the internal resilience of the pastoralist SES. (A black and white version of this figure will appear in some formats. For the colour version, please refer to the plate section.) 
- Where do they result in adverse ecological impacts through, for example, illegal grazing versus intended ecological benefits?

- Where do they lead to adverse socioeconomic outcomes through elite or state capture (whether of CBNRM resource access, or of PES and/or PWC) versus intended poverty reduction outcomes?

We focused initially on households around the Mara - of our five in-depth study sites, the only one where conservation income is of demonstrably high importance to many households, and cited by many policymakers and practitioners as leading the way, despite Mara's distinctive (and arguably nonreplicable) context. Common property resource games based on Maasai Mara grazing resources have explored the ways conservancies prompt changes in livelihood decisions. These games represent the closest we can come to controlled experiments studying household decision-makers' behaviour, presenting alternative investment opportunities - livestock, conservancy revenue or cash-earning activities - under different permutations of land tenure scenarios. Successive rounds may or may not include a drought year, in which payoffs to the different investment choices change dramatically. The games explore situations where individual interests can conflict with those of the group: where individual decisions can mean that too many animals are set to graze on the same land unit, conditions deteriorate and all herds suffer.

Alongside economic games, stochastic dynamic programming (SDP) models were also used to explore decisions made by single households over a 15-year timeline (the period for which land must commonly be covenanted to setaside by households wishing to join a conservancy). SDP allows calculation of the theoretically optimal decision sets for households of differing wealth and in different policy scenarios.

Choice experiments are described here in more detail to illustrate our approach to exploring conservancy effects on well-being. These field experiments offer choices between pairs of alternative livelihood futures, each with contrasting levels of herd size, crop area, wage, land set aside, etc. On the basis of the choices made, the experimenter estimates threshold values at which decisions change, and thus values representing equivalence between alternative options (Keane et al., 2016). The results of these choice experiments, carried out with 388 respondents (189 men, 199 women) around Maasai Mara National reserve in Kenya in 2013 are set out below. Full details of the sample and of the procedures are given in Keane et al. (2016).

Figure 9.4 shows marginal rates of substitution for each of the choice attributes in terms of cattle, based on a model which differentiates between men/women and members/non-members, but not between other respondent characteristics. For example, for male non-members, a monthly wage of 10,000 KSh (Kenyan shillings) is approximately equivalent to 76 (95 percent 


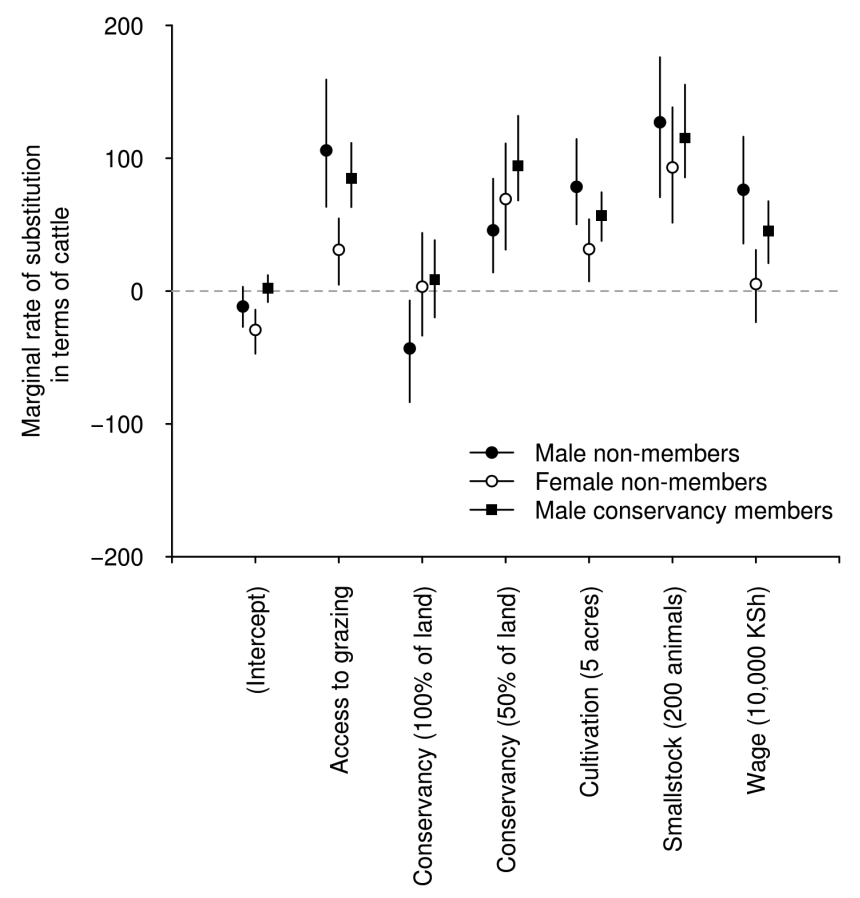

Figure 9.4 Marginal rates of substitution (in terms of cattle numbers) for different land-use and livelihood decision choices.

Credible Interval [CI]: 36, 116) head of cattle. For male conservancy members, it is worth 45 (95 percent CI: 21, 68) head of cattle, but for female non-members this monthly wage only rates five head of cattle (95 percent CI: 23, 31). Figure 9.4 also shows marginal rates of substitution for access to grazing, for covenanting half or all of a household's land to conservancy, for small-scale cultivation and for the value placed on a flock of 200 small stock, in terms of the numbers of cattle seen as approximately equivalent to each of these options. The individual results are interesting. For example, it is striking that Maasai - customarily known as 'people of cattle' - all place such a high value on small stock. In each case respondents are divided into male conservancy members, male and female non-members. For example, women non-members place lower values on access to grazing, and on a man's regular cash wage, than do male non-members - meshing with other studies suggesting women have little knowledge of or access to cash earned by their husbands (Bedelian, 2014). The differences these groups display in their valuing of different components of livelihoods are further explored in Figures 9.5-9.7 and below.

Figure 9.5 shows the proportion of the respondents captured in our sample who would choose to covenant their land to conservancy membership under three different scenarios: (1) when grazing is allowed on conservancy land during times of drought, (2) when grazing is not allowed on conservancy land 


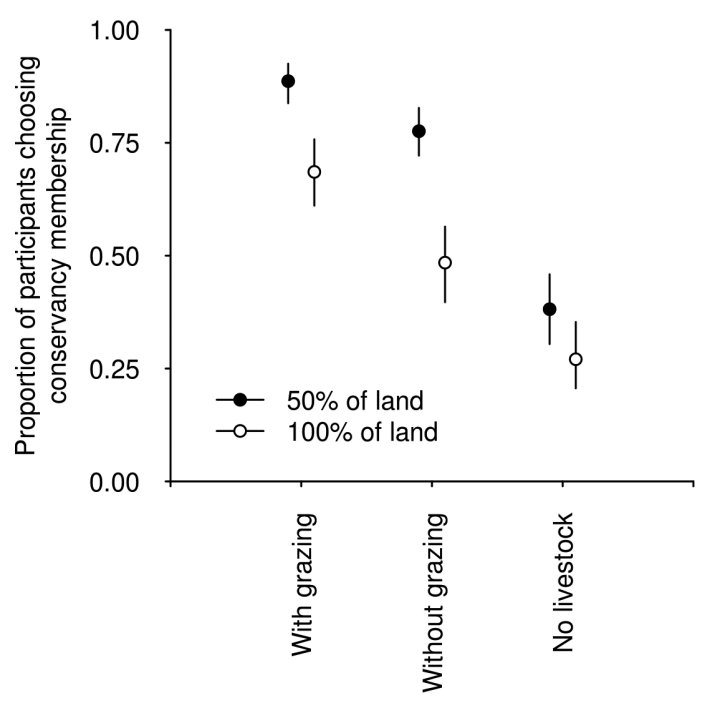

Figure 9.5 The proportion of respondents choosing to covenant their land to conservancy membership under different grazing allowance scenarios.

and (3) when grazing is not allowed and as a consequence no livestock can be kept, alongside two levels of conservancy membership (50 percent or 100 percent of household land placed under conservancy management). In each case, the alternative scenario is assumed to be one in which the household owns 40 head of cattle and 80 sheep or goats, cultivates 5 acres of land, and earns 6000 KSh per month in income from wages. Cultivation and wage earnings are assumed to be unaffected by conservancy membership. Figure 9.5 is based on a model including all of the recorded participant characteristics as covariates. While the great majority of participants chose conservancy membership when grazing is possible, Figure 9.5 makes clear people's preferences to set aside part rather than all of their land, and to do so preferably where dry season grazing is allowed. It also shows the powerful disincentive effect of conservancy management precluding livestock keeping.

Figure 9.6 shows the same data as Figure 9.5 above, but splitting the respondents into men $(N=189)$ and women $(N=199)$. Both show rather similar patterns, and the main gender difference to emerge here is that access for grazing is less important to female non-members. Women participants show marginally more interest in conservancy membership than do male nonmembers and are less put off by restrictions on dry season grazing.

Figure 9.7 again shows the same data as Figure 9.6, but splitting the respondents into those who were not conservancy members at the time of the survey $(N=149)$ and those who were $(N=239)$. Interestingly, there is a suggestion of unmet demand for more conservancies here - many non-members choose the scenario involving conservancy membership, provided this is compatible with maintaining their livestock. Conversely, even among existing conservancy 

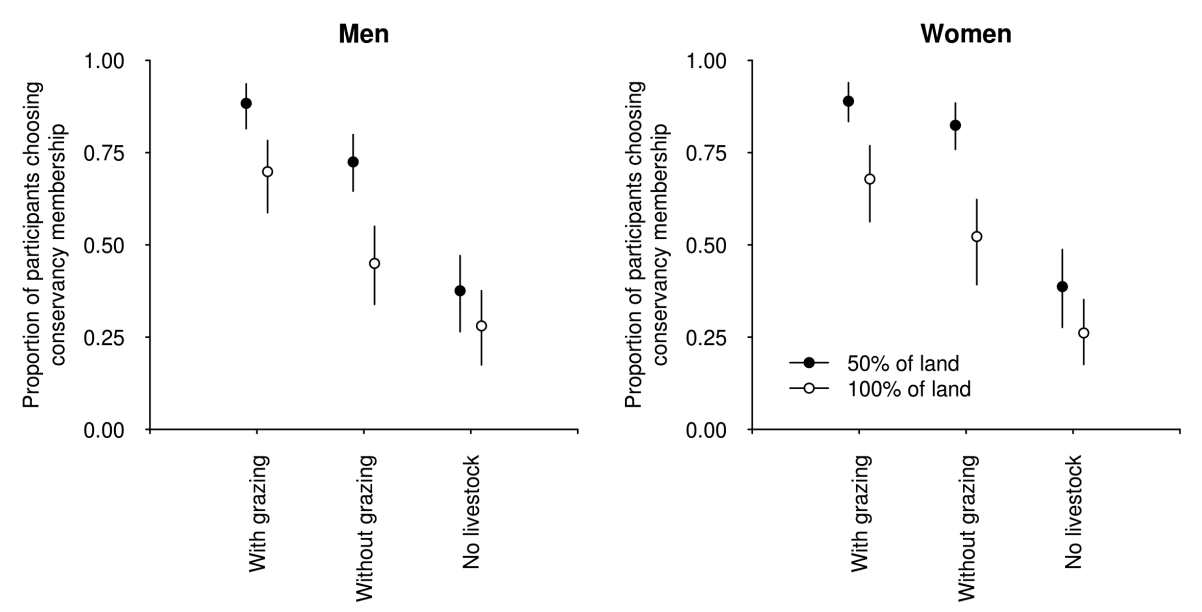

Figure 9.6 Responses of men and women to the option of conservancy membership under different grazing allowance scenarios.
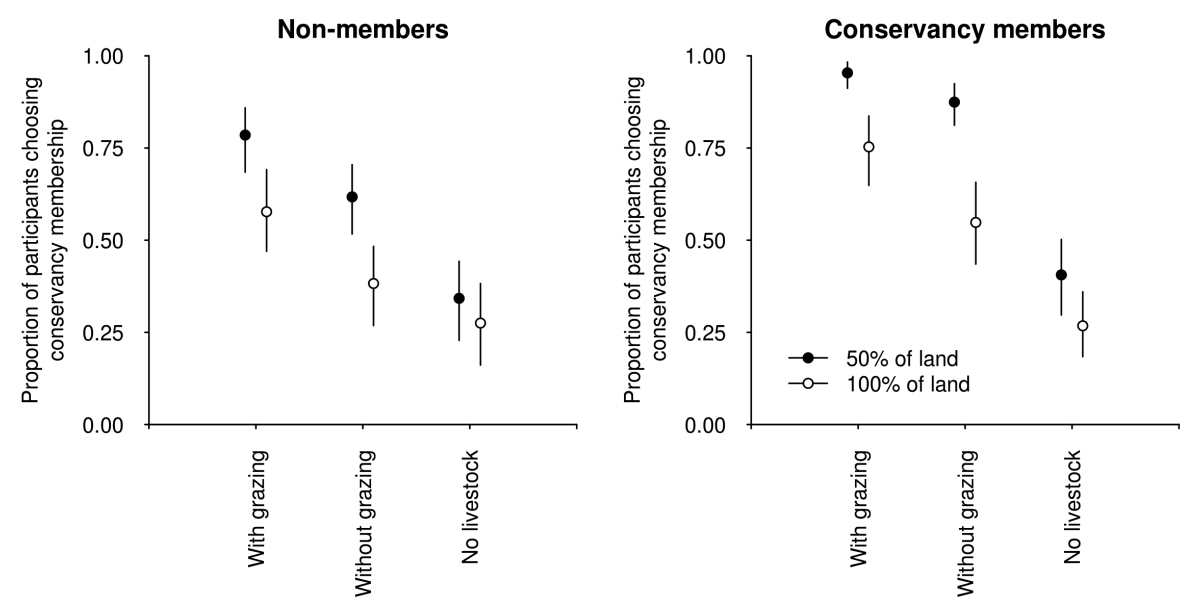

Figure 9.7 Responses of non-members and conservancy members to the option of covenanting land under different grazing allowance scenarios.

members, management scenarios or household choices meaning they would not be able to have grazing land, or that would undermine livestock keeping, are a clear disincentive to participating in conservancies.

\section{Discussion}

The results of this work help elucidate pastoralist decision-making and its implications both for the interplay of pastoralism and conservation, and 
for resilience of both the pastoralist production system and wildlife populations in East African rangelands. We set out to explore how conservation set-aside affects pastoralist household decisions over land use and livelihoods. As predicted by our overarching conceptual model, changes both in land availability (captured in our conservancy scenarios which set aside 50 percent or 100 percent land), and in the level of PES/ PWC payments (built into our experimental choices), lead to changes in people's evaluation of alternative options, and consequently in their landuse and livelihood decisions.

Outcomes include changes in the extent to which people invest in cattle as land tenure changes, and choices to maintain grazing access in the face of expanding conservancy set-aside. The outcomes are sensitive to context, with strategies (and theoretically optimal choices) shifting according to household wealth and land tenure context. The experiments make it possible to disentangle variables relating to the scenario under exploration (land tenure system; household wealth; proportion of wealth invested in livestock) and individual characteristics of participant players, which can also be significant predictors of outcomes (Keane et al., 2016). For example, people with more cattle in real life allocate more resources to cattle when making decisions within our experimental scenarios.

We wanted to explore the economic and ecological outcomes of these decisions, and the trade-offs and sometimes unanticipated outcomes they involve. Conservancies maintain open rangeland both for wildlife and also potentially for livestock, as in Kenya's Northern Rangeland Trust conservancies. However, around the Mara, as well as in most Tanzanian Wildlife Management Areas (WMAs), herds are usually only allowed under severe restrictions, or not at all. Conservancy managers explain this as necessary because tourists in high-end conservancy camps do not wish to see Maasai with cattle. Elsewhere, such as in the Northern Rangelands Trust, exclusion or tightly controlled grazing patterns for pastoralist cattle stems from adherence to a particular (much debated) theory of 'holistic management' (Savory, 1988). Denial of grazing access is at the root of much of the conflict, resentment and illegal behaviour associated with rangeland conservancies in Kenya and WMAs in northern Tanzania. It is continually contested and in some cases access has been successfully negotiated, both in Mara conservancies and some Tanzanian WMAs. Our findings make clear that monetary returns do not compensate for loss of grazing access; conservation and tourism-based livelihoods are seen as complementary, not as alternative to livestock and livestock-based activities, nor as fully compensating for their loss. These ecological and economic trade-offs are highlighted in the way most participants in our experiments made land-use choices, with diversification common but with the almost universally preferred choices being 
those guaranteeing access to dry season grazing within the conservancy, over alternative benefits.

Our choice experiments illuminate household decisions that underpin trends reported by independent lines of evidence. For example, the universally high value placed on small stock in choice experiments confirms and helps explain existing aerial survey data showing increasing numbers of small stock in the area, and the increasing proportion they make up of all livestock there (cf. Ogutu et al., 2011). Local informants cite the relative ease of management of Dorper sheep within reduced grazing areas, and high market prices, as factors driving this trend.

We sought to explore how impacts differ by wealth, gender and age, and between households in different circumstances (e.g. conservancy members versus non-members).

Empirical observation and theoretical prediction have long seen households as starting with small stock and progressively, with increasing wealth, switching to large stock (with or without cash investment). Our findings suggest that changing land tenure scenarios can shift optimal household strategies away from this classic progression with increasing wealth. The choice experiments highlight a divergence between men and women's interests at the level of the household over land-use and livelihood strategies, particularly with respect to cash payments from conservancy and from wage employment, respectively. Although the data are not detailed here, choice experiments also show significant age effects, for example in preferences for cattle (Keane et al., 2016).

These findings offer potential for fine-tuning policy and economic incentives to encourage more economically and ecologically sustainable livelihood choices in the face of rapid pace of change and shifting baselines, not least through recognising the major effect of (externally set) PES thresholds on decisions. Around the Mara, Kenya's highest-earning wildlife tourism destination, the value Maasai place upon access to land and mobility for grazing animals means that setting aside 50 percent of one's land in a conservancy scheme is seen as more acceptable than covenanting 100 percent of one's land. In other study areas, where the income from wildlife is less important to the household, the incentives and the will to set land aside for conservation are far lower.

The choice experiments reveal underlying decision rules and unanticipated outcomes. For example, our findings show the potential of PES/PWC for divergent effects on the well-being of men and women within the household. This is thought to stem from men and women's different degrees of access to and control of different income streams. Maasai men earning a cash wage are very unlikely to share it with their womenfolk, nor to divulge the amounts involved (Bedelian, 2014). While conservancy payments are made to a bank 
account established in the name of, and controlled by, the (usually male) household head, they involve standard sums paid at known points in time (often coinciding with the dates when school fees fall due). Even though they cannot access or control these monies directly, women are in a better position to press for these funds to be used to the benefit of the wider household than is the case with men's wages. The findings help make policymakers aware of the perspectives and responses of grassroots users, hopefully informing more effective policy and practice.

Ongoing work is currently exploring the detail of these issues. For example, economic games not reported here explore the way increasing conservancy set-aside drives choices to graze illegally in formally gazetted areas (particularly by those benefiting most from conservancy revenue, and thus most able to pay cash fines if caught - c.f. Butt, 2011). Further work is needed to investigate emerging questions around who is or is not able to engage with conservancies; how measuring broader dimensions of well-being might change conclusions; and on the social, economic and ecological leakage effects on surrounding areas (Bedelian, 2014). Modelling could explore overall effects at the community level of multiple, heterogeneous households' decisionmaking, identifying winners and losers at the household level.

Our choice experiments were conducted with people responding to the expansion of conservancies in Kenya's highest-earning wildlife tourism site. However, the insights they reveal are generalisable to the many initiatives attempting to use PES or PWC incentives to bring about socially and environmentally sustainable conservation across East African rangelands. As outlined in our introduction, such initiatives span a wide range, from those covenanting privately owned land to conservancies (as in, but also beyond the high-PES Mara area), to Tanzania's WMAs (where communal, rather than private, land is pooled and set aside to form multi-village WMAs, and the state taxes PES revenue heavily: Homewood et al., 2015), to local conservation easements negotiated with conservation NGOs (e.g. in Kitengela, Kenya: Homewood et al., 2009) or with tour operators (e.g. in Simanjiro, Tanzania: Leslie \& McCabe, 2013). Households' and individuals' responses are contingent not only on wealth, gender and occupation (this chapter; Keane et al., 2016) but also on perceived well-being, including noneconomic dimensions such as autonomy, security, identity and aspirations (Woodhouse et al., 2015). Conservation initiatives that fail to balance benefits, broadly defined, with the costs that people experience, or fail to distribute those benefits sufficiently equitably, ultimately undermine both social and ecological resilience. Supposedly community-based conservation initiatives may then elicit passive resistance, subversive or illegal behaviours, or outright conflict (Greiner, 2012; Mariki et al., 2015; Homewood et al., 2015; Homewood, 2017; Galvin et al., 2018). 
This work thus has wider applicability in exploring whether policies promoting and governing PES can enhance financial sustainability in lessfavourable areas, for whom and how. Our findings apply to conditions for a wider set of conservancies in Kenya, throughout Tanzania, across East Africa, the Horn and beyond. This research could also be extended to explore the implications of changing climate conditions. It develops a better understanding of household-level processes driving landscape-level changes, and starts to unpick the potential for rangeland policy to generate unexpected consequences.

Beyond its immediate applied use, this work contributes a new layer to our understanding of the resilience or otherwise of pastoralist social ecological systems. Findings to date are consistent with the broader conclusion that while mobile pastoralism can be highly resilient to external biophysical drivers, and shows a fine-tuned and rapid response to changing socio-political and economic factors, the interaction of external biophysical changes and new external socioeconomic drivers (political marginalisation of pastoralist peoples in modern nation states, global human population growth, globalisation, resource grab for large-scale cultivation and for conservation) are creating trends of rangeland loss and conversion that pastoralist SESs may not be equipped to survive. The same drivers, alongside the ratchet effects of increasingly frequent extreme climatic events, are undermining the resilience and ultimately the survival of savanna biodiversity. Work on pastoralist household decision-making aims to inform resource users, conservation workers, development planners, policymakers and donor agencies as to the ways that people's behaviour may respond to opportunities and constraints in these shifting contexts.

In wider perspective, the current downward spiral of pastoral rangelands, their people and wildlife, is thus perhaps best understood by looking beyond internal and local effects to the overwhelming pressures of external market forces and global capital currently converting pastoral rangelands, constraining local choices and driving adverse local social and environmental outcomes. While that overarching context offers little cause for optimism, the internal resilience of pastoralist social-ecological systems can be better understood and managed by taking into account the way local behaviours represent finetuned strategic responses to local political and economic drivers, including the perverse incentives these may set up.

\section{Acknowledgements}

This work builds on research projects Biodiversity, Ecosystem Services, Social Sustainability and Tipping Points in East African rangelands (BEST), NE/1003673 and Poverty and Ecosystem Impacts of Tanzania's Wildife management Areas (PIMA), $\mathrm{NE} / \mathrm{L} 00139 \mathrm{X} / 1$, both funded with support from the Ecosystem Services for 
Poverty Alleviation (ESPA) programme. The ESPA programme is funded by the Department for International Development (DFID), the Economic and Social Research Council (ESRC) and the Natural Environment Research Council (NERC). We would like to thank the Governments of Kenya and of Tanzania, respectively, for their permission to carry out field work associated with these research projects, the Kenyan and Tanzanian communities who participated in the research, and our field research colleagues Heather Gurd, Dickson ole Kaelo and Stephen Sankeni, as well as other colleagues too numerous to mention from UCL, Imperial, ILRI, ATPS, TAWIRI, TNRF and Copenhagen University. We are grateful to an anonymous reviewer for constructive suggestions on an earlier draft.

\section{References}

Adams, W.M. \& Hutton, J. (2007). People, parks and poverty: political ecology and biodiversity conservation. Conservation and Society, 5, 147-183.

Agarwala, M., Atkinson, G., Palmer Fry, B. et al. (2014). Assessing the relationship between human wellbeing and ecosystem services: a review of frameworks. Conservation and Society, 12(4), 437-449.

Anderson, D. \& Broch-Due, V. (eds.). (1999). The Poor Are Not Us. Oxford: James Currey.

Barrett, C., Travis, A.J. \& Dasgupta, P. (2011). On biodiversity conservation and poverty traps. Proceedings of the National Academy of Sciences, 108, 13907-13912.

BBC. (2013). Tanzania's Maasai battle game hunters for grazing land. www.bbc.co.uk/ news/world-africa-22155538 (accessed 30 August 2013).

Bedelian, C. (2014). Conservation, tourism and pastoral livelihoods: wildlife conservancies in the Maasai Mara, Kenya. PhD thesis, University College London.

Behnke, R. \& Muthami, D. (2011).

The contribution of livestock to the Kenyan economy. IGAD LPI Working Paper 03-11. Addis Ababa, Ethiopia.

Benjaminsen, T. \& Bryceson, I. (2012) Conservation, green/blue grabbing and accumulation by dispossession in Tanzania. Journal of Peasant Studies, 39(2), 335-355.
Blaikie, P. (2006). Is small really beautiful? Community-based natural resource management in Malawi and Botswana. World Development, 34, 1942-1957.

Bluwstein, J., Homewood, K., Lund, J.F., et al. (2018). A quasi-experimental study of impacts of Tanzania's wildlife management areas on rural livelihoods and wealth. Scientific Data, 5 [180087] on https://doi.org/ 10.1038/sdata.2018.87

Butt, B. (2011). Coping with uncertainty and variability: the influence of protected areas on pastoral herding strategies in East Africa. Human Ecology, 39(3), 289-308.

Butt, B. \& Turner, M.D. (2012). Clarifying competition: the case of wildlife and pastoral livestock in East Africa. Pastoralism: Research, Policy and Practice, 2(9), doi:10.1186/ 2041-7136-2-9.

Catley, A., Lind, J. \& Scoones, I. (eds.). (2012). Pastoralism and Development in Africa: dynamic change at the margins. Abingdon: Earthscan/ Routledge.

Coast, E. (2002). Maasai socio-economic conditions: cross-border comparison. Human Ecology, 30(1), 79-105.

Craigie, I.D., Baillie J.E.M., Balmford, A., et al. (2010). Large mammal population declines in Africa's protected areas. Biological Conservation, 143, 2221-2228. 
Davies, J. \& Nori, M. (2008). Managing and mitigating climate change through pastoralism. In Policy Matters, 16, Commission on Environmental, Economic and Social Policy, IUCN-CEESP, pp. 127-141.

DFID (2011). Defining Disaster Resilience: a DFID approach paper. London: Department for International Development.

Dressler, W., Buscher, B., Schoon, M., et al. (2010). From hope to crisis and back again? A critical history of the global CBNRM narrative. Environmental Conservation, 37, 5-15.

du Toit, J.T., Kock, R. \& Deutsch, J.C. (eds) (2010). Wild Rangelands: conserving wildlife while maintaining livestock in semi-arid ecosystems. Chichester: Wiley-Blackwell.

Duvail, S., Médard, C., Hamerlynck, O. \& Nyingi, D.W. (2012). Land and water grabbing in an East African coastal wetland: the case of the Tana delta. Water Alternatives, 5(2), 322-343.

Ellis, F. (2000). Rural Livelihoods and Diversity in Developing Countries. Oxford: Oxford University Press.

Emerton, L. (2001). The nature of benefits and the benefits of nature. In: African Wildlife and Livelihoods: the promise and performance of community conservation, edited by D. Hulme \& M. Murphree. Oxford: James Currey. For a more detailed treatment see: www .sed.manchester.ac.uk/idpm/research/publi cations/archive/cc/cc_wp05.htm.

Fairhead, J., Leach M. \& Scoones I. (2012). Green grabbing: a new appropriation of nature? Journal of Peasant Studies, 39(2), 237-261.

Folke, C. (2006). Resilience: the emergence of a perspective for social-ecological systems analyses. Global Environmental Change, 16, 253-267.

Fratkin, E. (2014). Ethiopia's pastoralist policies: development, displacement and resettlement. Nomadic Peoples, 18, 94-114.

Fratkin, E. \& Roth, E. (2005). As Pastoralists Settle: social, health, and economic consequences of the pastoral sedentarisation in Marsabit District, Kenya. Dordrecht: Kluwer Academic Press.

Galaty, J. (1999). Grounding pastoralists: law, politics and dispossession in East Africa. Nomadic Peoples 3(2), 56-73.

Galaty, J. (2014). “Unused” land and unfulfilled promises: justifications for displacing communities in East Africa. Nomadic Peoples, 18, 80-93.

Galvin, K.A. (2009). Transitions: pastoralists living with change. Annual Review of Anthropology, 38, 185-198.

Galvin, K.A., Beeton, T.A. \& Luizza, M.W. (2018). African community-based conservation: a systematic review of social and ecological outcomes. Ecology and Society, 23(3), 39.

Gough, I. \& McGregor, J.A. (eds.). (2007). Wellbeing in Developing Countries: new approaches and research strategies. Cambridge: Cambridge University Press.

Greiner, C. (2012). Unexpected consequences: wildlife conservation and territorial conflict in Northern Kenya. Human Ecology, 40, 415-425.

Haviland, W.A. (2003). Anthropology. Belmont, CA: Wadsworth.

Homewood, K. (2017). "They call it Shangri-La": sustainable conservation, or African enclosures? In: The Anthropology of Sustainability: beyond development and progress, edited by M. Brightman \& J. Lewis. New York, NY: Palgrave Macmillan.

Homewood, K. \& Rodgers, W.A. (1991). Maasailand Ecology: pastoralist development and wildlife conservation in Ngorongoro, Tanzania. Cambridge: Cambridge University Press, reprinted 2004.

Homewood, K., Lambin, E.F., Coast, E., et al. (2001). Long-term changes in Serengeti-Mara wildebeest and land cover: pastoralism, population or policies? Proceedings of the National Academy of Science, 98(22), 12544-12549.

Homewood, K., Kristjanson, P. \& Chenevix Trench, P. (2009). Staying Maasai? Livelihoods, conservation and development in East African rangelands. New York, NY: Springer. 
Homewood K., Chenevix Trench, P. \& Brockington, D. (2012). Pastoralist livelihoods and wildlife revenues in East Africa: a case for coexistence? Pastoralism: Research, Policy, Practice, 2(19). www .pastoralismjournal.com/content/2/1/19

Homewood, K., Bluwstein, J., Lund, J., et al. (2015). The economic and social viability of Tanzanian wildlife management areas. Policy Briefs No. 4, Copenhagen Centre For Development Research. http://ccdr.ku.dk/ policy_briefs/

HRBDF. (2013). Ethiopian sugar alleged to destroy pastoral communities of Lower Omo, Ethiopia. Human Rights and Business Dilemmas Forum, http://human-rightsforum.maplecroft.com/showthread.php? 15012-Ethiopian-Sugar-Alleged-to-DestroyPastoral-Communities-of-Lower-OmoEthiopia\&s=6a203e6 $\mathrm{c} 83 \mathrm{c} 733 \mathrm{e} 2 \mathrm{c} 18220 \mathrm{adfd}$ ea0c2c ( accessed 30 August 2013).

Igoe, J. \& Croucher, B. (2007). Conservation, commerce and communities. Conservation and Society, 5, 534-561.

Inter-Réseaux Développement Rural. (2012). Pastoralism in Sub-Saharan Africa: Know its Advantages, Understand its Challenges, Act for its Sustainability. Food Sovereignty Brief, no. 5 (7 pp). Available at www.fao.org/ fileadmin/templates/agphome/documents/ rangelands/BDS_pastoralism_EN.pdf

IWGIA. (2013). Forced evictions of pastoralists in Kilombero and Ulanga Districts in Morogoro Region in Tanzania. Briefing Note. IWGIA (International Work Group For Indigenous Affairs) Classensgade $11 \mathrm{E}$, DK 2100 - Copenhagen, Denmark. 5 pp.

Jones, S. (2006). Political ecology of wildlife conservation in Africa. Review of African Political Economy, 33(109), 483-495.

Keane, A., Gurd, H., Kaelo, D., et al. (2016). Gender differentiated preferences for a community-based conservation initiative. PLOS ONE, 11(3), e0152432. doi:10.1371/ journal.pone.0152432

Lambin, E.F. \& Meyfroidt, P. (2011). Global land use change, economic globalisation and the looming land scarcity. Proceedings of the National Academy of Sciences of the USA, 108, 3465-3472.

Leslie, P. \& McCabe, J.T. (2013). Response diversity and resilience in social-ecological systems. Current Anthropology, 54(2), 114-143.

Letai, J. \& Lind, J. (2012). In: Pastoralism and Development in Africa: dynamic change at the margins, edited by A. Catley, J. Lind, \& I. Scoones. Abingdon: Earthscan/Routledge.

Mariki, S., Svarstad, H. \& Benjaminsen, T. (2015). Elephants over a cliff: explaining wildlife killings in Tanzania. Land Use Policy, 44, 19-30.

Marshall, F., Reid, R., Goldstein, S., et al. (2018). Ancient herders enriched and restructured African grasslands. Nature, 561, 387-391.

McPeak, J.G., Little, P.D. \& Doss, C.R. (2011). Risk and Social Change in an African Rural Economy: livelihoods in pastoralist communities. London: Routledge

Milner-Gulland, E.J., Mcgregor, J., Agarwala, M., et al. (2014). Accounting for the impact of conservation on human well-being. Conservation Biology, 28, 1160-1166.

Nelson, F. (ed.). (2010). Community Rights, Conservation \& Contested Land: the politics of natural resource governance in Africa. London: Earthscan.

Nelson, F. (2012). Natural conservationists? Evaluating the impact of pastoralist land use practices on Tanzania's wildlife economy. Pastoralism: Research, Policy and Practice, 2(15). www .pastoralismjournal.com/content/2/1/15

Nelson, F. \& Agrawal, A. (2008). Patronage or participation: community-based natural resource management reform in Sub-Saharan Africa. Development and Change, 39(4), 557-585.

Niamir-Fuller, M. (ed.). (1999). Managing Mobility in African Rangelands: the legitimation of transhumance. London: Intermediate Technology Publications. 
Niamir-Fuller, M., Kerven, C., Reid, R. \& MilnerGulland, E.J. (2012). Co-existence of wildlife and pastoralism on extensive rangelands: competition or compatibility? Pastoralism: Research, Policy and Practice, 2(8). doi:10.1186| 2041-7136-2-8

Norton-Griffiths, M. \& Said, M. (2010). The future for wildlife on Kenya's rangelands: an economic perspective. In Wild Rangelands: conserving wildlife while maintaining livestock in semi-arid ecosystems, edited by J. Deutsch, J. Du Toit \& R. Kock. London: Zoological Society of London Symposium volume with WCS, pp. 367-392.

Odadi, W.O., Karachi, M., Abdulrazak, S. \& Young, T.P. (2011). African wild ungulates compete with or facilitate cattle depending on season. Science, 333, 1753-1755.

Ogutu, J., Owen-Smith, N., Piepho, H.P. \& Said, M. (2011). Continuing wildlife population declines and range contraction in the Mara region of Kenya during 1977-2009. Journal of Zoology, 285, 99-109.

Ogutu, J., Owen-Smith, N., Piepho, H.P., Kuloba, B. \& Edebe, J. (2012). Dynamics of ungulates in relation to climatic and land use changes in an insularised African savanna ecosystem. Biodiversity and Conservation, 21(4), 1033-1053.

Osano, P. (2013). Direct payments to promote biodiversity conservation and the implication for poverty reduction among pastoral communities in east African arid and semi-arid lands. $\mathrm{PhD}$ thesis, McGill University, Canada.

OXFAM. (2010) Disaster Risk Reduction in Drought Cycle Management: a learning companion. London: Oxfam Disaster Risk Reduction and Climate Change Adaptation Resources.

Prins, H.H. (2000). Competition between wildlife and livestock in Africa. In: Wildlife Conservation by Sustainable Use, edited by H.H.T. Prins, T. Geu Grootenhuis \& T. Dolan. Boston, MA: Kluwer Academic Publishers, pp. 53-80.

Randall, S., Coast, E. \& Leone, T. (2011). Cultural constructions of the concept of household in sample surveys. Population Studies A Journal of Demography, 65(2), 217-229. doi:10.1080/00324728.2011.576768.

Reid, R., Fernández-Giménez, M. \& Galvin, K. (2014). Dynamics and resilience of rangelands and pastoral peoples around the globe. Annual Review of Environment and Resources, 39(1), 217-242.

Robbins, P. (2012) Political Ecology: a critical introduction. 2nd edn. Chichester: Wiley.

Robinson, L. \& Berkes, F. (2010). Applying resilience thinking to questions of policy for pastoralist systems: lessons from the Gabra of northern Kenya. Human Ecology, 38 (3), 335-350.

Rockström, J., Steffen, W., Noone, K., et al. (2009). A safe operating space for humanity. Nature, 461(7263), 472-475.

Savory, A. (1988). Holistic Resource Management. Washington, DC: Island Press.

Scoones, I. (2009). Livelihoods perspectives and rural development. Journal of Peasant Studies, 36(1), 171-196.

Sinclair, A.R.E. \& Arcese, P. (1995). Serengeti II: dynamics, management and conservation of an ecosystem. Chicago, IL: Chicago University Press.

Sinclair, A.R.E. \& Norton Griffiths, M. (1979). Serengeti I: dynamics of an ecosystem. Chicago, IL: Chicago University Press.

Sinclair, A.R.E., Packer, C., Mduma, S. \& Fryxell, J. (2008). Serengeti III: human impacts on ecosystem dynamics. Chicago, IL: Chicago University Press.

Spencer, P. (1988). The Maasai of Matapato: a study of rituals of rebellion. Manchester: Manchester University Press for the International African Institute.

Sternberg, T. \& Chatty, D. (2012). Modern Pastoralism and Conservation: old problems, new challenges. Whitstable: White Horse Press.

Sulle, E., Lekaita E. \& Nelson, F. (2011). From Promise to Performance? Wildlife Management Areas in Northern Tanzania. www.maliasili.org/publications/WMA\% 20TNRF\%20Brief\%20Nov\%202011.pdf 
Thompson, D.M., Serneels, S., Ole Kaelo, D. \& Chenevix Trench, P. (2009). Maasai Mara land privatisation and wildlife decline: can conservation pay its way? In: Staying Maasai? Livelihoods, conservation and development in East African rangelands, edited by K. Homewood, P. Kristjanson \& P. Chenevix Trench. New York, NY: Springer.

URT. (2005). Mkukuta: Tanzania's national strategy for growth and reduction of poverty. Dar es Salaam: United Republic of Tanzania: VicePresident's Office.

URT. (2010). Mkukuta II: national strategy for growth and reduction of poverty II. Dar es Salaam: Ministry of Finance and Economic Affairs, United Republic of Tanzania.

Walsh, M. (2008). The not-so-Great Ruaha and hidden histories of an environmental panic in Tanzania. Journal of Eastern African Studies, 6(2), 303-335.

Western, D., Groom, R. \& Worden, J. (2009a). The impact of subdivision and sedentarisation of pastoral lands on wildlife in an African savanna ecosystem. Biological Conservation, 142, 2538-2546.

Western, D., Russell, S. \& Cuthill, I. (2009b). The status of wildlife in protected areas compared to non-protected areas of Kenya. PLoS ONE, 4(7), e6140.

Wisner, B., Blaikie, P., Cannon, T. \& Davis, I. (2004). At Risk: natural hazards, people's vulnerability and disasters. London: Routledge Publication.

Woodhouse, E., Homewood, K.M., Beauchamp, E., et al. (2015). Guiding principles for evaluating the impacts of conservation interventions on human well-being. Philosophical Transactions of the Royal Society B: Biological Sciences, 370, 1681.

Zoomers, A. (2010). Globalisation and the foreignisation of space: seven processes driving the current global land grab. Journal of Peasant Studies, 37(2), 429-447. 


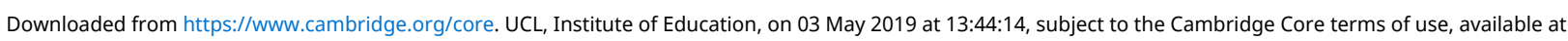
https://www.cambridge.org/core/terms. https://doi.org/10.1017/9781107705555.010 